\title{
MUSLIM VIEWS ON ORGAN TRANSPLANT
}

\author{
AbDi O. SHURIYe \\ Department of Science in Engineering, Faculty of Engineering, \\ International Islamic University Malaysia, \\ P.O. Box 10, 50728 Kuala Lumpur, Malaysia. \\ shuriye@iium.edu.my
}

\begin{abstract}
In Islamic worldview human cadaver is considered holy and sacred as of the living person. The human dignity bestowed on all mankind applies and it is extended to the corpse. For this reason, in the Muslim world at least, organ transplant has been contentious process. This paper is a study on the procedures and ethical implications of organ transplant. It evaluates the Islamic views on the issue.
\end{abstract}

ABSTRAK: Pada panndangan Islam, mayat manusia adalah suci dan mulia sebagaimana orang yang masih hidup. Atas sebab ini, pemindahan organ dalam dunia Islam memerlukan proses yang teliti. Kertas ini mengkaji prosedur dan implikasi etika pemindahan organ dari sudut pandangan Islam.

KEYWORDS: organ transplant; ethics; religion;Muslim views

\section{INTRODUCTION}

An organ transplant is a surgical operation in which a failing or damaged organ in the human body is removed and replaced with a functioning one. The donated organ may be from a deceased donor, a living donor. The objective of this paper is to thrash out both cadaveric and living organ transplants. The significance of this research is that it studies the issue from the perspective of the Qur'an [1]. The research contends that religious and ethical predicaments in organ transplantation relate to religious beliefs, organ donation process, organ allocation to recipients, and commercialization and shortages of human organs.

\section{THE NATURE AND BACKGROUND OF ORGAN TRANSPLANT}

Originally the term organ is derived from a Greek term organon which denotes tool or instrument. Transplant as a term refers to move or transfer something to another place or situation, with some effort or upheaval [2]. Specific usage of transplant refers to moving living tissue or an organ and implant them in another part of the body or in another body as it indicates the operation in which an organ or tissue is transplanted, or a person or a thing which has been moved to a new place or situation [3].

The combination of the two terms organ and transplantation, or organogenesis as it is also known, gives the meaning of moving part of the biological organism from certain place in the body to another place or from another person or animal to another. In other words organ transplant would mean taking an organ from one person through surgery and then placed into another person whose own organ has failed because of illness or injury.

Historically speaking, transplantation of living tissues and organs has begun in the nineteenth century; J.L. Reverdin triumphantly described in 1869 skin grafts and C. 
IIUM Engineering Journal, Vol. 12, No. 5, 2011: Special Issue on Science and Ethics in Engineering

Shuriye

Tiersch systemized it. These were however, transplantations of tissue within the same patient. It was soon applied into the treatment of server burns and repair skin defects. However, in late 1880 s treatment centres made certain attempts to test tissues by using skins of cadavers or of amputated limbs though there was no concrete result from such experiments. Then by late 1930s, E. Ullmann of Vienna, experimented on autotransplantation of parts of the intestine in the heterotypic sites, which later marked the beginning of living organ transplantation $[3,4]$.

\section{THE PROCESS OF ORGAN TRANSPLANT}

Obviously, in order for a candidate to receive an organ, a donor has to be available. In cases like bone marrow, some kidney transplants and a small number of liver transplants, the donor may be a person who shares the same compatibility of tissue and immune system responses that creates a match. When an organ becomes available for donation, the organ is offered to the candidate that is the best match, based on the criteria set by the given organization, including the waited period, medical history, and severity of the illness. Note that once removed from the body, organs can only be stored for a short period of time. For the purpose of the process of kidney transplantation blood test be run for urea nitrogen, also urine output is necessary, this is done without neglecting the health status of the patient [3].

One of the methods to excise the renal from the donor is laparoscopy [5]. Laparoscopy is done, under anesthetic condition, by making a small incision next to the navel. A laparoscope is passed through the peritoneum, a membranous sac lining the abdominal cavity. The abdomen is swelled by passing carbon dioxide or nitrous oxide gas into the peritoneal cavity. The organs are then, in this case, recovered from the donor [5]. In performing heart transplantation two current types of procedures are identified; the orthotopic and heterotopic approaches. The choice between these two procedures highly depends on the patients themselves and the time consumption for each approach differs from one patient to another [5].

The orthotopic procedure involves replacing the recipient's heart with the donor's. In other words, the recipient's damaged heart will be excised and removed for good. The donor's heart must be transplanted into the recipient within four to five hours after it is removed, preserved and packed [5]. The heterotopic procedure does not involve removing the original heart. Instead, the new heart received from the donor will be placed next to the damaged heart and it will function in parallel with the recipient's original heart. Despite this advantage of having a 'back-up' heart, this procedure is still rarely done compared to the orthotopic approach [5].

Liver Transplantation procedure was first attempted on human by Dr. Thomas Starzl in 1963 and it underwent improvements in subsequent years, especially with the discovery of a better and promising immunosuppressant therapy. The recent rate of survival has encouragingly increased up to 73 percent per year [3].

Methods used to perform liver transplantation are similar to the heart transplantation approaches i. e. orthotopic and heterotopic, with the same notion of either dissecting and removing the recipient's old liver or leaving it were it is and adding in a new liver to function in parallel with the old one.

Lung Transplantation is also an old method. Although Dr. Hardy successfully performed in 1963, the first single lung transplant, the possibility of developing lung transplants was still very low and vague, as complications arise from organ rejection, 
IIUM Engineering Journal, Vol. 12, No. 5, 2011: Special Issue on Science and Ethics in Engineering Shuriye

infection and insufficient healing hindered further success [3]. In the process the patient may have to undergo several regular checks on respiratory systems to detect and control failures before any other complications occur. The damaged lung is normally removed by excising it from the main blood vessel attachments to the heart and bronchus [3].

\section{MUSLIM VIEW POINTS ON ORGAN TRANSPLANT}

One of the basic teachings of Islam is the preservation and protection of human life from body to batin (inner) prohibiting murder and massacre and grievance against any one unlawfully. The Almighty presaged Muslims on the matter in the Qur'an.

"If a man kills a Believer intentionally, his recompense is hell, to abide therein (forever): and the wrath and the curse of Allah are upon him, and a dreadful penalty is prepared for him”. (Qur'an, 4:93)

Under the Islamic legal system therefore, the punishment of a murder of any human life pays a life price:

"O you believe the law of equality is prescribed to you in cases of murder the free for the free, the slave for the slave, the women for the women. But if the brother of the slain makes any remission, then grant any reasonable demand. And compensate him with handsome gratitude. This is a concession and a mercy from your Lord. After this, whoever exceeds the limits shall be in grave penalty”. (Qur'an, 2:178)

The Qur'an also repetitively reminds its believers that humans are dignified, honored and favored over other creatures by Allah; dignity of life and death therefore has to be preserved.

"Nor take life, which Allah has made sacred-except for justice cause. And if anyone is slain wrongfully, we have given his heir authority (to demand qisas or to forgive) but let him not exceed bounds in the matter of taking life, for he is helped (by the law". (Qur'an, 17:33)

Similarly the Qur' an makes life sacred:

"We have honored the sons Of Adam; provided them with transport on land and sea; given them fro sustenance things Good and pure; and conferred on them special favors, above a great part of Our Creation". ( Qur'an, 17:70)

Manifestations of danger to human life such as violence, destruction and economic sanctions, are strictly prohibited.

"O you who believe! Eat not up your property among yourselves in vanities; But let there be among you Traffic and trade by mutual good will: nor kill (or destroy) yourselves: for verily Allah have been to you most merciful".

(Qur' an, 4:29)

In line with the Qur'anic teachings, majority of the Muslim scholars have invoked the principle of priority of saving human life and has permitted the organ transplant as a necessity to procure that noble end. Nonetheless it is prohibited to violate, harm or mutilate the cadaver whether it is a Muslim or a non-Muslim. There are exceptions to this general rule especially in a case when there is a necessity (darurah). One question could be underscored that if the donor is alive he or she may undergo normal surgical operation 
but can the body of a dead donor undergo surgical procedures? The assessment of the views of the Muslim Jurists may shed some light on the issue.

Muslim jurists hold diverse opinions on the aforementioned question. The Maliki and Hanbal schools maintain that it is impermissible to dissect a dead pregnant lady in order to retrieve the infant. The Shafi'i school of thought on the other hand allows dissection to be carried out. Dissection to remove valuable items from the dead is also allowed according to the mainstream of Muslim jurists, except the Hanbali School [6]. Maliki and Hanbali's opinion on pregnant lady to salvage the infant may not be relevant at this stage due to the technological development.

A Council consists of the scholars from the major Muslim Schools of law in Britain had painstaking deliberated on the issue of organ transplant and concluded that:

"The medical profession is the proper authority to define the signs of death. Current medical knowledge considers brain death to be a proper definition of death. The Council accepts brain-stem death as constituting the end of life for the purpose of organ transplant. The Council supports organ transplant as a means of alleviating pain or saving life on the basis of the rules of shari' ah. Muslims may carry donor cards. The next of kin of a dead person, in the absence of a donor card or an expressed wish of the dead person to donate his organs, may give permission to obtain organs from the body to save other people's lives" [7].

In his work, Fiqh al-Islami wa Adillatuh, Wahba az-Zuhaili insists that:

"Based on the ruling, which allows dissection on dead bodies in specific cases, any dissection or operation done on the dead body due to a significant necessity is allowable. For example, dissection for the knowledge of medicine and dissection in order to find the cause of death to convict criminals by which there are no other avenues to come to the truth (al-Haq). These are based on the shari'ah principle of establishing justice, Adil, in any ruling given by the court, in order to avoid injustice, Dhalim, from happening to the innocent or to ensure that the guilty do not escape from the punishment as a result of his crimes. Even though such dissections are allowed, it should be done within necessary limits without overdoing it. Besides, the sanctity of the dead body has to be respected and handled properly. After the investigation, bits and pieces should be gathered, suturing it up and finally shrouding the body should close the body. It is also allowable to perform any organ transplant such as the human heart or the eye. This must be with the condition that the donor is proven to be dead by a specialist in the field. This is because the priority is given to the living. The success of recovering vision for a human is a wonderful gift and is demanded by the shari 'ah" [8].

The Permanent Committee for Legal Rulings in the Saudi Kingdom concluded the following on dissection: 1. Dissection to discern criminal act caused the death of the diseased is sanctioned. 2. Dissection to identify contagious disease and finding methods of sojourning its spread is also endorsed. 3. Dissection for educational and training purposes is authorized [9].

Islam requires that the donor be mature and mentally sane, able to decide his or her destiny through free will and in full control and comprehension. The intention to trade an organ or exchange it with other organs is considered unlawful contract between donor and recipient, as humans should not put their body on the market. The life of the donor should not be in danger as a result of the organ removal. It is not permissible also to donate essential organs such as the brain, nervous system and other crucial parts even to the 
IIUM Engineering Journal, Vol. 12, No. 5, 2011: Special Issue on Science and Ethics in Engineering

donors' loved ones. On this aspect Muslim scholars are in agreement on the illegitimate nature of donating life to another person $[9,10]$.

Muslim Jurists also divided organ donors into two main groups, dead and a live, putting each category under certain conditions. On the living donor the aforementioned conditions such as being mature, sane, responsible and able to make personal decisions apply. On the organ from dead persons jurists have permitted taking certain organs from diseased body with the following conditions in place:

1. The deceased should have permitted before his or her death

2. It should not be for the purpose of commerce and pecuniary

In an article entitled transplantation of cells of Nervous System, specially the Brian”, Sheikh Mohamad al-Mukhtar, a contemporary Muslim scholar, divided the Donors into four categories: Respected or honourable adults, Minors, the foetus, and adults whose life is not protected by Islam [11].

Faith has also been made a factor in the discussion of Muslim Jurists on organ transplant. It appears there is consensus that transplant is permissible from one Muslim to another and from a non-Muslim to a Muslim. Transplanting Muslim organs into those under Muslim protection is however a matter subjected to some disagreement while the transplant of Muslim organs into non-Muslims is not permitted according to the mainstream of Muslim jurists [11].

On the Xenotransplantation, the halalicity of the organ is relevant. The Qur'an prohibited Muslims to make use of or benefit from non-halal organs.

"Forbidden to you (for good) Are: dead meat, blood, On which hath been invoked the name of other than Allah; that which hath been Killed by strangling, or by a violent blow, or by a headlong fall, or by being gored to death; that which hath been (partly) Eaten by a wild animal; unless you are able To slaughter it (in due form; That which is sacrificed On stone (altars); (forbidden) also id the division (Of meat) by raffling with arrows: that is impiety”. (Qur'an, 5:3)

In another related verse the Qur' an permits the use of the haramized organs on the basis of complelling necessity, (darurah):

"He has only forbidden you what has died by itself, blood and pork, and anything that has been consecrated to something besides God. Yet anyone who may be forced to do so, without craving or going too far, will have no offence held against him; for Allah is Forgiving, Merciful” (Qur'an, 2:173).

\section{CONCLUSION}

The research found that transplantation of living organs has begun in the nineteenth century and developed to be used in the treatment of server burns and repair skin defects. The researcher is of the opinion that the process of organ transplant has never been straightforward. It explained laparoscopy as a method used in the process of organ transplant. Laparoscopy is done, under anesthetic condition, by making a small incision next to the navel. Another procedure used is orthotopic procedure. It involves replacing the recipient's heart with the donor's. In other words, the recipient's damaged heart will be excised and removed for good. The donor's heart must be transplanted into the recipient within four to five hours after it is removed. Nonetheless organ transplant involves ethical 
IIUM Engineering Journal, Vol. 12, No. 5, 2011: Special Issue on Science and Ethics in Engineering Shuriye

and religious issues. One of the basic teachings of Islam is the preservation and protection of human life from physical to psychological and from emotional to spiritual.

\section{REFERENCES}

[1] Al-Qur'an al-Karim

[2] Judy Pearsall (ed), The New Oxford Dictionary of English, Oxford, University Press, 2001

[3] Abdi O. Shuriye, Islamic Ethical Values on Bioengineering Practices: Issues in Genetic Engineering. Research Management Centre, IIUM, pp. xiv- xvi, 2006

[4] W.F. Bynum and Roy Porter (eds.) Companion Encyclopedia of the History of the Medicine, Routledge, London, 1993

[5] The Organ Procurement and Transplantation Network. About donation: living donation, Retrieved July 23, 2004, http://www.optn.org/about/donation/livingdonation

[6] Muhamad al-Din, Ad-Dirar al-Mukhtar, Law Publishing, Lahor-Pakistan, 1970

[7] http://www.islamicvoice.com.

[8] Wahab az-Zuhaili, Al-Fiqh al-Islamiyi wa Adilatuhu, Dar al-Fikr, Damascus, Syria, 1989

[9] Abdul Aziz Khalifah Al-Qussar, Hukum Tashrih al-Insan, bayna Al-Shariati Wal Qa'nun, Dar Ibn Hazmi, Beirut, ${ }^{\text {st }}$ edition, 1999, p.80

[10] Al-Qussar, Dr, Abdul Aziz Khalifah, Hukum Tashrih al-Insan, bayna Al-Shariati Wal Qa' nun, Dar Ibn Hazmi, Beirut, 1999, p. 88

[11] Sheikh Mohamad al-Mukhtar, Transplantation of Cells of Nervous System, specially the Brian. Majalah Majama' al-Fiqh al-Islami, the $6^{\text {th }}$ Seminar of the Majma', pp.1747-1756 